\title{
Mining Rehabilitation in New South Wales (Australia) and Germany
}

\author{
Lisa J. K. Zillig ${ }^{1}$, Naomi Keenan ${ }^{2}$ and Tim Roberts ${ }^{2}$ \\ 1. University of Duisburg-Essen, Essen 45141, Germany \\ 2. Tom Farrell Institute for the Environment, the University of Newcastle, Callaghan NSW 2308, Australia
}

\begin{abstract}
The rehabilitation of coal mines is an up-to-date issue, heavily discussed not only by the industry but also by scientists and the adjacent communities since open cut coal mining has extensive impacts affecting all parties. Whereas, before and during the mining process not only nature but sometimes also the population of a whole region has to give way to a mine, the consequences of the operations remain long after mining closure. Typically a once intact and functioning ecosystem is replaced with a destroyed wideness evocative of a moon landscape. Fortunately, the awareness of the need to rehabilitate the destroyed nature is increasing steadily and all involved parties are making efforts to improve the situation, even if it is a major challenge to bring all parties to a consensus. Therefore, a legislative basis is required and the know-how of optimal rehabilitation solutions must be developed. In this article the rehabilitation of mined land in Australia and Germany are compared. More precisely the article will present an overview of the legislative regulations, certain applied methods of rehabilitation work and the problems that are likely to occur in respect to the influence of mining on nature.
\end{abstract}

Key words: Mining rehabilitation, mining Australia, mining Germany, mine closure, legislation mining rehabilitation.

\section{Introduction}

Coal mining forms an important industry branch, which covers a large segment of the steadily growing demand of energy in our society. While coal mining entails infrastructure and jobs for whole regions, it often also leaves behind massive natural destruction. It cannot be denied that coal mining has a high impact on the environment and even though new methods for "clean energy" are being worked out, the consequences of the past and present practiced mining industry have to be dealt with. Especially open cut coal mining is an important sector of the industry, causing heavy destruction of our nature. Open cut mining is practiced both in Australia and Germany, but while in Australia black coal is mined with this procedure, Germany mainly extracts lignite (brown coal) in open cut mines (black coal has to be mined with underground mines). Both countries are among the leading nations in mining the respective resource.
Thereby they have a special responsibility when it comes to a sustainable management of the consequences of mining to set a good example for others to follow. Even if Australia and Germany are differing in their geographically conditions, the two have in common that coal mining largely influenced the development and formation of infrastructure of hole regions. Like this, the "Hunter Valley" in Australia and the "Ruhrgebiet" in Germany are typical areas whose identity in mainly imprinted by coal mining. Whereas the opinions of the residents differ on coal mining, it is economically still very important for the countries, even if, at least, Germany, aims to a long-term change to renewable energy. Nevertheless a responsible and sustainable solution for mining rehabilitation has to be drawn up in both countries. Therefore, the legislative regulations and dealing with the rehabilitation of New South Wales in Australia and Germany are presented in the following.

Corresponding author: Lisa J. K. Zillig, Bachelor candidate. 


\section{Legislative Regulations}

\subsection{New South Wales-Australia}

In Australia, the mining legislation is under the control of the different states and territories since the Commonwealth has no national mining legislations.

In this way, NSW, a state with an immense mining industry, is responsible for its own regulation of mining rehabilitation.

"Mining has been part of NSW for more than 200 years [...]. Coal mining in Australia began near Nobbys Head in Newcastle in the 1790s [...]" [1].

Despite the long existing mining industry in NSW, the first mining regulations only came into effect in 1992: "The Mining Act 1992 No 29", and with this legislation act the rehabilitation regulations came along.

The "Mining Act 1992 No 29" commits to the protection of the environment. In part 11 of the mining act, it is defined that the impacts on environment has to be considered before the grant of mining authorities:

"Need to protect natural resources etc. to be taken into account

(1) In deciding whether or not to grant an authority or mineral claim, the Minister or mining registrar has to take into account the need to conserve and protect: (a) the flora, fauna, fish, fisheries and scenic attractions, and (b) the features of Aboriginal, [...] or geological interest, in or on the land over which the authority or claim is sought.

(2) The Minister or mining registrar may cause such studies (including environmental impact studies) to be carried out [...]" [2].

However, specific descriptions on the rehabilitation work are not given, rather possible treatments are listed:

"Rehabilitation etc. of area damaged by mining

(1) The conditions subject to which an authority or mineral claim is granted or renewed may include such conditions relating to: (a) the rehabilitation, $[. .$.$] of the$ land $[\ldots]$ affected by prospecting operations or mining operations, and (b) the filling in, sealing or fencing off of excavations, shafts and tunnels, as may be prescribed [...]" [2].

The costs of the rehabilitation have to be covered completely by the mining companies, generating huge costs [3]. This might lead to the effort of making the rehabilitation as efficient as possible in order to make it more attractive for the mining companies to carry out their responsibilities.

To create a certain kind of guarantee that the mining companies are not only willing but also able to fund the rehabilitation work, all Australian states are applying so called "Performance Guarantee Bonds". These mainly serve the following functions:

"First, these bonds provide a direct financial incentive for companies to comply with their rehabilitation requirements. [...] The second function of performance bonds, that the other mechanisms do not provide, is that they "insure" governments against the event that a company becomes insolvent and is unable to fund the required rehabilitation" [3].

Since the "Mining Act 1992 No 29" was established long after mining itself, there are a significant number of derelict mines from the time prior to the legislative regulations that have not been rehabilitated. To rehabilitate these, the "Mining Act 1992 No 29" arranges a "Derelict Mines Site Fund" to finance the rehabilitation work on the unclaimed land [2].

The "Derelict Mine Program" allows the repair of some earlier abandoned mines. The program was initiated "[...] in 1974 with an annual allocation of $\$ 125,000$ " [4].

As mentioned above, the rehabilitation work is regulated by the single states of Australia. The Commonwealth recently established the "Environment Protection and Biodiversity Conservation Act, 2000". Through this contract: "[...] the Commonwealth can become involved in the determination of such requirements for particular projects [...]" [3].

But how is NSW ensuring that the rehabilitation 


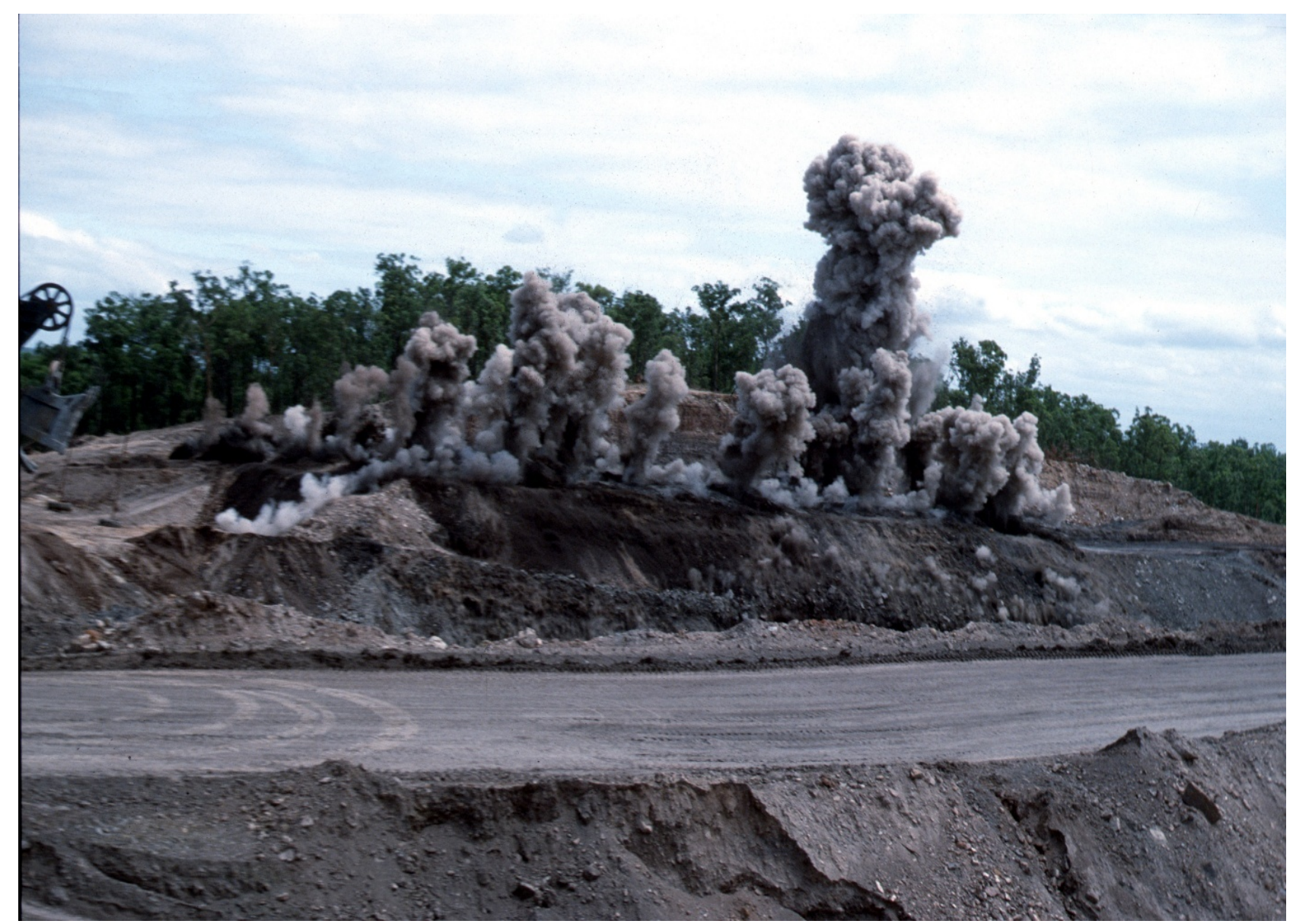

Fig. 1 Blasting in an open cut mine. Clouds of dust rise as blasting occurs in an open cut mine, Newcastle.

Source: CSIRO Creative Commons.

work is done by the companies? To guarantee an optimal outcome of the mine closure and rehabilitation there are already actions taken in the run-up to the approval of a mine site and during the mining process. Therefore, a mining company is obligated to release a "MOP" (mining operation plan) that needs to be approved by the department prior to the mining operations. The guidelines defined in the MOP are controlled frequently during the life of a mine to insure its relevance and provide the possibility to respond to changed circumstances. Before the draft of the MOP an "EIS" (environmental impact statement) has to be approved. During the mining operations, an "AEMR" (annual environmental management report) has to be released by the mining company [4].

In this way the NSW-Government supervises the environmental implications and the rehabilitation measures of each mining site. Thus, an individual coordination of the rehabilitation actions with reference to the respective environmental conditions and mining methods of a particular mining site is possible.

The latest developments in the NSW-mining policies could lead to a new Mining SEPP (state environmental planning policy) with stronger regulations being effective already in the planning phase, involving greater protection for the population and environment [5].

\subsection{Germany}

The history of brown coal mining in Germany began sometime in the late $17^{\text {th }}$ century in the area known today as the "Mitteldeutsches Braunkohlerevier", motivated by the need of a new 
heating-fuel since most of the forest providing firewood had been cleared. From this time an early example of a recultivation regulation is found in the leasehold of a pit in Brühl [6].

While former mines had been installed by more or less simple techniques, modern mining was established in the still operating "Rheinische Braunkohlerevier" in 1978. Followed by the "Lausitzer Braunkohlerevier "and the "Mitteldeutsche Braunkohlerevier" in 1990 [7].

However, in the former GDR (German Democratic Republic) the rehabilitation work was divided into different sections. The first phases scheduled to make the area "usable" again ("Wiedernutzbarmachung") and was incumbent on the mining company. But the second phase which included the (biological) re-cultivation remained in the hands of the purchaser of the mined land [8].

To administer the mining processes in the whole of Germany, the government released the Federal Mining Act "Bundesberg Gesetz" (BBergG) that was drafted in 1980 and became effective at January the $1^{\text {st }}$, 1982. This law comprises the processes of every operation relating to mining, beginning at the exploration over the extraction of the coal up to the conservation of the environment and the rehabilitation of the mine [9].

Concentrating on the conservation of the environment and the rehabilitation of mined land, the Federal Mining Act provides an "assessment of the environmental impact" ("Umweltverträglichkeitsprüfung"). The mining company is bound to release a frame-operation plan which contains amongst others, all necessary information for the assessment of the environmental impact, including:

"The description of the likely significant effects of the project on the environment under consideration of the general state of knowledge and the general accepted assessment methods.

$[\ldots]$
The description of the measures to prevent, reduce or if possible compensate serious damage to the environment, as well as alternative measures for not compensable but extensive intrusion in nature and landscape" [9].

This implies that the undertaken measures of rehabilitation do not necessarily lead to the reestablishment of the former ecosystem but replace the mine site with a natural valuable outcome. But usually a basic draft of the after-mining-landscape is already established in the approval procedure of the mine [10].

Beyond the regulations on national ground, the Federal Mining Act also considers how to proceed in cases where neighboring states are influenced by mining operations: "The projects that could cause a significant impact on the environment in another [...] (state), must be reported to the responsible authorities of the affected state and the authorities involved in the planning-approval-process" [9].

All in all, the German regulations on mining - the Federal Mining Act-is considered as "best practice" in other European countries, because of its comparatively high protection and prevention requirements for the environment [11].

But still, there are different regulations in the single German states for rehabilitation. Therefore the Federal Environment Minister developed and proposed a "federal compensation enactment" ("Bundes Kompensations Verordnung" BKompV) to establish a universally valid principle for rehabilitation [12].

The financing of the rehabilitation work in Germany is, like in NSW, incumbent upon the mining companies but areas where no company now exists the rehabilitation is covered by a cooperated funding of the federal government and the affected states [13].

\section{Likely Issues Caused by Mining \& Rehabilitation Methods}

Mining is an industry sector that on the one hand provides jobs for a large part of some communities. 
On the other hand the long term impacts on the environment and also on society can be immense. For example, 5 villages are going to be relocated in the area of the German mine "Garzweiler II" to make space for extended mining works (Fig. 2) [14].

The disturbance of the nature by mining also accelerates steadily, which makes rehabilitation increasingly difficult. Especially the restoration of the former landscape is usually not possible and therefore the goal of rehabilitation is more often to gain a functional ecosystem with a certain degree of biodiversity. One of the reasons why the restoration of the original ecosystem is not always possible is that the physiochemical and biochemical conditions of the original soil and the post mining soil are different. Therefore, the goal for post mining landscapes should be the highest possible quality of environmental outcome [15].

Different rehabilitation scenarios are considerable:

(1) "Least impact": The irreparable landscape is curtailed as much as possible to enable a way back to the natural landscape that was present on the undisturbed area of the mining site. This approach needs a prior assessment of the environmental function and long-term surveillances accompanied by a strict environmental management strategy [15].

(2) "Conventional practice": Considers that severe anthropogenic disturbance may be unavoidable and the maximal disturbance impact is overstressing the dimension of ecological resilience of the former ecosystem. "Still, the reconstruction of a natural landscape in accordance with pre-disturbed ecosystem function can be achieved through the [...] management of various biotic and abiotic factors [...] to attain a land-use value comparable to the undisturbed landscape" [15].

(3) "Shifting ecological function": Implies an installation of a "novel" ecosystem to the mined landscape since the impact of mining made a restoration of the old ecosystem impossible. For example, an agricultural land-use is often considered [15].
(4) "Social and environmental irresponsible": In this case the rehabilitation work has not been sufficient or did not happen at all, which could lead, in a really unlikely case, to a reclamation of the mine site by the natural ecosystem or, more likely, stays disturbed [15].

To enable the growth of plants on a mining site at all, it is necessary to take a look at the soil first, since that is literally the foundation of all following rehabilitation processes. However the soil of a mine site is usually in extreme conditions with a heavy lack of nutrients and a high level of toxicity. Therefore, the beginning of every rehabilitation is the soil remediation. Unfortunately the development of proper soil can take thousands of years, taking the breakdown of rock material and clay minerals into account. But fortunately the biological soil development, including the building of organic matter, the enrichment of nitrogen and other nutrients and the nutrients cycling process itself, is much faster. Because of that, the interactions between soil structure and function are crucial. To develop a soil ecosystem microbes and micro fauna are fundamental to get the nutrient cycle moving again. In addition, pioneer plants not only protect the soil from erosion but also accumulate the nutrients and make them accessible to the soil as organic matter again. In this form they are more easily available for the microbial breakdown. An important role in this process plays the so-called rhizobia, a symbiosis of nitrogen fixing micro-organisms and plant roots. On extremely acidic soil, only acid tolerating species are able to survive, but with their presence the soil quality usually improves, conditioning the area for other species [16].

Usually the top soil covering the mining area is abraded and stored before mining to replace it after the mining process. But when it is replaced to the mining site for rehabilitation, the top soil cannot always connect to the deeper soil layers, which might end in unstable ground conditions [16].

A few methods to overcome physical problems of 
the soil are as follows:

Typically the soil structure after mining is not adequate for future rehabilitation. On the one hand the soil density could be too high to allow root growing caused by the pressure of the heavy mining machines and a loosening method is necessary. On the other hand the erosion provoked by the lack of stabilizing plants can be handled with planting fast growing plants and in addition a cover of mulch [16].

While the treatment of nutritional problems can be handled with a fertilizer to initiate the natural cycling process, a low $\mathrm{pH}$ level caused by oxidation processes can require a treatment with limestone [16]. Another important factor crucial for the development of a post-mining ecosystem is the immigration of different species [15]. Therefore, it is necessary not only to establish an attractive environment for (flora and) fauna but also to make it accessible to them. That means that the rehabilitation sites need a link to other habitats to build "green corridors" for species immigration [17].

To put it in a nutshell, rehabilitation is composed of "[...] sequential steps: (1) site characterization, (2) reclamation planning and engineering, (3) material management, (4) topographic reconstruction, (5) replacement of topsoil or soil substitute, (6) surface manipulation, (7) addition of soil amendments, (8) vegetation, (9) irrigation, if needed, (10) site monitoring and maintenance" [18]. And it is always important to take a look at the whole extent of the ecosystem that is involved to gain the best possible outcome. "From lessons of the past, it is clear that close collaboration and transparent dialogues on rehabilitation options between proponent, regulator and other stakeholders are required [...]" [15].

\subsection{New South Wales-Australia}

A few examples of rehabilitation work and examination in New South Wales are provided to allow a deeper insight into the issue.

One method often applied for rehabilitation planning is emphasizing the conditions under which the new landscape is going to be created. To give a prediction of the possible outcome of the rehabilitation work it can be sensible to take a look at a given ecosystem and to determine its fitness (ecosystem service). Moreover, aspects like the climate, geology, landform and soil substrates need to be taken into consideration while thinking about potential rehabilitation measures. To decide, for example, between the installation of a "natural" or a "novel" ecosystem it should be weighed up how many of the crucial biotic and abiotic factors will be on the post mining site. On top of that, influential components of an ecosystem can be determined by looking at so-called "reference sites" (sites with the same ecosystem). Possibly adjacent areas would be suitable for this method, since they are built on the same (former) soil and landform combinations. To determine the future fate of the mining site, these parameters can help to decide between a rehabilitation of the former ecosystem or an alternative, for example an agricultural land use. But nevertheless, the resource inputs and the time required for the desired rehabilitation techniques still need to be estimated [15].

To measure the success of the rehabilitation of an ecosystem the recolonization of a mining site by fauna should be regarded. Since fauna is inter alia responsible for the fertilization and transport of plant diaspora it is an essential part of every ecosystem. Normally fauna should follow flora automatically but only in less than half of the study plots to analyze the fauna on mined land in Australia could prove an equal or better fauna density than on undisturbed land. Connotative characteristics that influence the recolonization of mined land are the climate, the shape of the mine site and its distance to undisturbed areas, the time since the mine closure and the degree of the flora improvement. Especially the divergent results for different animal classis are noteworthy. While Aves are the most successful recolonization-group, 
Mammalia density is often worse than on undisturbed land. Some aspects that are considered to improve the fauna density are the use of fresh topsoil, the improvement of the vegetation structure and composition and additional measures to facilitate the recolonization for certain animals, for example providing nest boxes etc. For the assessment of the success of rehabilitation, a long term monitoring of the fauna density and fitness is also required [19].

With a proved record of success the Glencore-owned Mt Owen Mine near Singleton was able to observe the return of two examples of the spotted- tailed quolls [20] which is classified as "near threatened" after the "International Union for Conservation of Nature and Natural Resources" (IUCN) [21]. The rehabilitation of this mine site is aimed at restoration of a natural woodland ecosystem, since it is located adjacent to the Ravensworth State Forest [20].

"The Australian Bureau of Agriculture and Resource Economics" (ABARE) discloses a range of efforts achieved and methods used in the mined land rehabilitation in their report on "mine site rehabilitation" in August 2001. A creditable example of collaboration to improve the rehabilitation process is the working group between "[...] Australia's mining industry (The Mineral Council of Australia, MCA) and government (the Australian and New Zealand Minerals and Energy Council, ANZMEC) (that) recently produced a set of principles and guidelines for mine site closure policies within Australia [...]" [22].

Several examples of different rehabilitation works provide an overview of the manifold potential of rehabilitation. To mention some of them: A bauxite mine has been successfully afforested after mining (Perth). The conclusion that has been drawn from the rehabilitation work is that the less time the topsoil is stockpiled before replacement, the higher is its quality. For example, it contains more fungi, bacteria and microfauna, that is crucial for the soil development as mentioned above. Another example is a rehabilitation with more or less a higher social value, such as the "Ballambi West" underground mine (NSW), which has been converted into a golf course. Lastly, the "Denehhurst Ltd's former Woodlawn mine" (NSW) has been modified into a dump with the extraordinary idea to collect the methane gas that is produced by the waste, to generate electricity. ABARE also alludes the increasing investment in rehabilitation and the improvement of rehabilitation techniques. This is faced by the concerns " $[\ldots]$ raised in the ANZMEC and MCA paper [...] (about the) current approaches to the design and administration of rehabilitation standards in Australia. It was suggested that current mine site rehabilitation standards are overly focused on structural and other technical criteria, and that more attention is required on the establishment of sustainable ecosystems as a long term goal" [22].

In the "Glencore-Annual Environment Review-2013" the company reports about three finished rehabilitation projects. A linkage of their "clear water system" has been completed where the water flows over a lime stone drain. A topsoil replacement followed by ground amelioration and seeding has also been conducted. The ground ameliorations were necessary since sediment samples indicated a slightly high acidity, low salinity, low exchangeable calcium and low available phosphorus. To equalize the deficits and enable plant growth the ground was treated with agricultural lime, gypsum, $\mathrm{N}$ and $\mathrm{P}$ fertilizer and organic mulching. The vegetation established in the three areas is a mixture of tree and shrub species. "The seed mix was a combination of selected pasture and local native tree seed species. The native tree seed species were collected from the UCML land holdings as part of the local provenance seed collecting program. A cover crop pasture mix was included in the seed mix to provide initial ground protection on erodible soils and slopes" [23]. As a part of the OMP (Offset Management Program), a clean water drain has been installed to catch up the water before it reaches the disturbed area and discharge it 
into the existing clean water drainage system. On top of this, a population of Wattle trees (Acacia ausfeldii) has been relocated. Beyond this: "A soil characterization-survey was undertaken at Ulan Coal Mine in October 2013 to monitor the status and temporal trends of the soil microbial communities of rehabilitating areas and to compare these to unmined analogue sites. Changes in soil microbial community status of the rehabilitating sites can be indicative of the initiation of soil formation or a need for further management inputs" [23].

The "WHITEHAVEN COAL MINING PTY LTD" expounds various measures of soil management in their "flora and fauna management plan". For example, a combination of subsoil and topsoil replacement is suggested, both with a depth of about $20 \mathrm{~cm}$. The soil layers are supposed to be spread over a plain but scarified surface. In addition, the topsoil needs to be roughened and drainage has to be installed as well, to ensure optimal water absorption and minimized erosion. The sub- and topsoil-layers should, if possible, originate from areas dominated by native species. In combination with biomass transferal, from, for example, previously cleared debris, this should induct an appropriate microclimate for vegetation establishment. To protect the freshly rehabilitated sites, some tree guards have been installed around planted seedlings to protect them against wind, as well as temporary and permanent fencing and fire protection [24].

At the "Wilpinjong Coal Mine" of the Peabody Energy company, a surface water management is operated to ensure the quality of the water that is discharged from the mine into the nearby Wilpinjong creek. The surface water around the disturbed areas is isolated and treated by a "reverse-osmosis-plant-treatment" before it is conducted to the fresh water. To guarantee the quality of the released water, precise specifications for the allowed $\mathrm{pH}$ - and conductivity-levels are outlined in the "Environment Protection Licence" [25]. This is one example of preventative mechanisms for environmental protection that are definitely as important as rehabilitation measures to warrant a sustainable solution for the regional ecosystem. In this way, certain types of environmental damage caused by mining, like dust, noise, air and water pollution, can be embanked already during the mining process [3].

Considering mining as an important entrepreneur and employer, the growing market for companies specialized on rehabilitation should also be mentioned. For example, the "ReGen" company offers complete solutions for mining closure including land form design, water management, revegetation and soil amelioration, just to mention an excerpt of their activities [26]. It is hoped that this new market development will lead to a fusion and evolution of rehabilitation to achieve the best possible outcome.

\subsection{Germany}

Also in Germany, various measures are taken to promote the rehabilitation of mined land.

The above mentioned use of mulching was already present in 1984 at the "Sophienhöhe" site. The soil consisting of loess and sand was covered with humus that was taken from an adjacent forest of the pre-mining area. This resulted in an increased micro-fauna density, since the organic matter is likely to contain a number of eggs, juveniles and adult soil animals. The better the soil fauna develops, the less additional fertilization is necessary. Another possible source for soil fauna invasion is warranted by planting, since a significant amount of micro-fauna is usually attached to the roots of plants [27].

Looking at the re-cultivation of the lignite open-cast mines in the Rhineland area in Germany the rehabilitated area is divided into different land uses. Next to recreation areas and almost natural forests there are commercial forests and agriculture land installed. The tree species used for the afforestation originate from the natural ecosystem of that region [27]. The collection of seeds in the adjacent areas is an important measure to preserve the genetic potential of 
the domestic forests [28]. Usually cover plants are used to support tree growth, but before seeding can be carried out, adequate soil conditions need to be restored. "Reclaimed lignite open-cast mine areas in the Rhineland are covered by a mixture of loess and sand deposits containing organic material that originates from the upper Quaternary soil which has been taken from the front of the mining path. Consequently, the soil fauna that has established itself on the reclaimed open-cast mine areas may result from the primary succession and also from species that are carried to the dumping mines and are able to survive the dumping process" [27].

To obtain a more authentic landscape a new technique was developed that omits the final leveling of the ground after soil replacement. Instead, the dumping technique produces troughs and crest with an altitude difference of about $80 \mathrm{~cm}$ in intervals of 150 $\mathrm{cm}$, with the aim of a better self-sustaining rehabilitation. Since it was discovered that the survival of micro-fauna at the beginning of the soil development is mainly dependent on the texture and the quality of organic material of the deposit, the micro-fauna species that are present in the first stages of the rehabilitation are usually adapted to extreme conditions and are able to increase the $\mathrm{pH}$-values, the ammonium-nitrogen content and decrease the level of aluminum ions. Another animal that certainly deserves its attention is the earthworm that contributes to soil improvement by increasing the water infiltration and retention capacity of the ground and enhances the accumulation of organic matter (by feces deposit), which in turn makes the site attractive for other species [27]. It was found, that the "[...] environmental conditions in the troughs were improved not only by erosion, but additionally by the soil fauna that directly enhanced microbial activity and indirectly increased the availability of macronutrients [...]" [27]. On top of this, the new technique revealed that the " $[\ldots]$ population densities of soil biota found in the troughs are higher than those on the crests (since the troughs provide more balanced physical conditions); (2) the enhanced values of the chemical properties found in the troughs of the recultivated areas clearly indicate an improved soil quality [...], obtained by the process of erosion and additionally by the activity of soil biota; and (3) diverse fauna and flora improve soil quality more effectively than is expected by the additive effects obtained by the influence of single species. This means that interactive processes between species contribute to improve soil quality, even within the initial phases of succession" [27].

An important aspect that complicates the soil development on mining sites is the fact that the dumping process reveals ground layers that have been covered for years. In the area of Niederlausitz these are usually marin-brackisch sediment layers that have been deposited in the Tertiary under low oxygen influence close to the coal seam. It comprises a high level of carbon, sulfur, iron, sulfide and, on top of that, mineral pyrite. The pyrite starts to oxidize when it comes to the surface, which leads to a high release of acid, sulfate and iron. Because of that, $\mathrm{pH}$ levels of 3 and even lower are possible. This, in turn, leads to an increase of the solubility of aluminum and heavy metal and a high salinity. Without a special treatment this ground would stay free of vegetation for decades. The, in the Nierderlausitz area in the 1960s a tried and tested, method has been developed to determine the necessary amount of alkaline power plant ash and lime that are spread over the contaminated area [29].

Another important factor that must be taken into consideration is the enormous volume deficit after mining. Thereby the post mining landscape in the Niederlausitz area includes much more surface water than the undisturbed area. That could encourage the development of new ecosystems if the water quality is reasonable [29].

Like the already described method practiced in NSW, the possible rehabilitation outcome in the Niederlausitz area is examined with the use of 
reference sites (chronosequenz-technique) [29]. On top of that, the chronosequenz-technique provides a comparison between, e.g., soil development on a disturbed and an undisturbed site. Like this, the "Development of the humus layer starts with an extremely high abundance of soil fungi, which is generally, much lower on comparable but undisturbed sites [...]. Later in the development of the humus layer, a relatively sudden increase of nitrogen mineralization activity occurs-again on a much higher level than would be typical for comparable N-poor non-mined sites" [30].

Depending on which ecosystem is going to be installed in the Rhineland mining area, different soil rehabilitation measures are undertaken. Where afforestation is planned, the topsoil consists of a mixture of gravel and loess loam. That is, on the one hand, loose enough to enable a good root penetration and on the other hand loamy to capture water efficiently. For rehabilitation to a cultivated area, the topsoil layer comprises mainly loess and loess loam. To enhance an optimal, nutrition storing humus, the planting of pioneer plants is necessary [28]. Often used species are trefoil, pastures, lucerne and lupine [31]. They enrich the soil with nitrogen (that may have to be provided through fertilization) [28]. After 7 years of preparation the area arranged for cultivation can be handed over to the farmers (who had been affected by land claim for mining). The farmers are supported financially in the first years if they have to forfeit their possible profit in favor of further humus buildup. Altogether the RWE Power AG is liable 25 years after the mining closure for the soil quality [28].

In another case, the Wismut $\mathrm{GmbH}$ closed contracts with the new owners of rehabilitated areas to ensure the landscape's recovery [32].

Of the $290 \mathrm{~km}^{2}$ of destroyed area, $200 \mathrm{~km}^{2}$ already have been rehabilitated. 300 ha have already been contributed to natural protection areas where, for example, 13 native orchid species are growing [28].

Next to forests and cultivation land, a lot of aquatic ecosystems have emerged. The flooding of the abandoned open pits with water from the surrounding creeks and rivers, gives fish the access to the new water body. A basic requirement for a new aquatic habitat is a minimum $\mathrm{pH}$ value of 5.5. Otherwise the fish would suffer from restrictions of their reproduction and there would also be vegetation dieback.

Nevertheless there are some acid tolerant species that are able to survive in environments with low $\mathrm{pH}$ values. The bass, for example, is able to overcome $\mathrm{pH}$ values of 4.0 (but not without harm). However, if an adequate $\mathrm{pH}$ value is achieved, characteristic fish species can be introduced that would not reach the water body on their own. On top of that, the new waters are connected to the adjacent rivers, creeks and lakes to give trout and eels, among others, the chance for their migration [31].

To mention a few general rehabilitation procedures that are illustrating the wide range and different facets of mined land restoration:

Ahead of the mining process, frogspawn is relocated and can be returned to in the shallow water area of the flooded pits after mining [28]. Furthermore, the water bodies in the open pits are utilized as flood compensation areas [33], or as a fire fighting water reservoirs [31].

The habitats of other species are also addressed. Nesting boxes and perches for birds are set up and whole ant colonies are relocated [28]. Furthermore, heaps of stones and brushwood hedges provide save refuges and the connection of different habitats [31].

The mining sites offer the basis for the development of a large biodiversity through their miscellaneous structuring. Like this, 50 percent of the animals of the red list of Sachsen-Anhalt could be detected in the rehabilitated areas [31].

Other areas are left over completely to nature. This practice allows the experimental observation of natural succession processes, without the intervention of human beings [31]. 


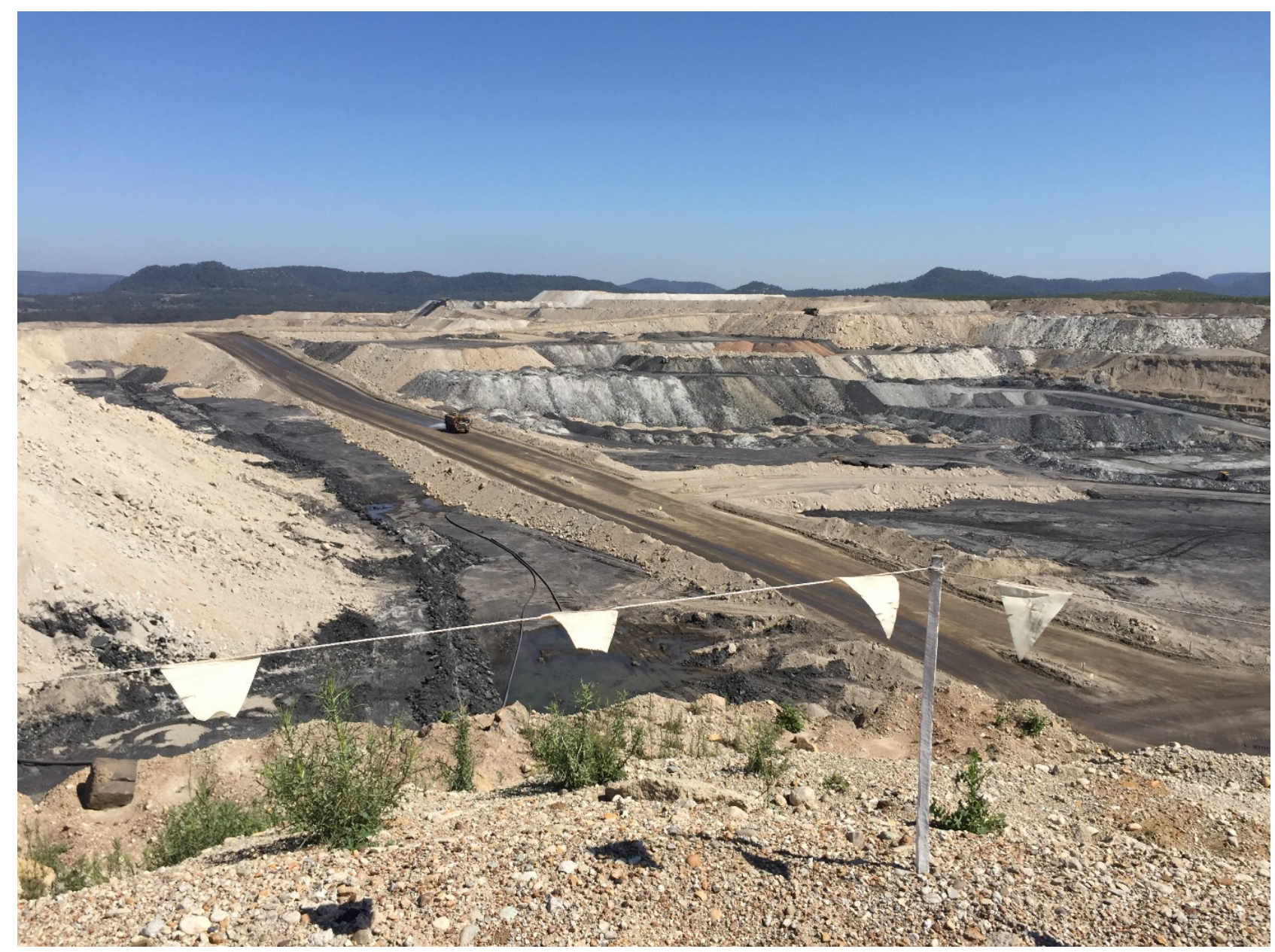

Fig. 2 Recent rehabilitation at the Mangoola Mine.

Source: photo T Roberts.

Another promising idea for restoration is the installation of a solar-power-plant on the 400 ha wide former uranium ore mined area in Thuringia [34].

This does not only provide a meaningful usage of once destroyed land, but also takes a step towards the shift to renewable energies that are hopefully replacing the need for coal and other fossil fuels. But how fast the conversion will be performed is unclear and the currently import of coal to Germany is likely to expand until then. Even then it will be important to ensure that the impacts on the environment, which the imported coal is causing, are repaired as well as the burdens in the own country.

\section{Conclusion}

The legislative regulations of mining differ in each country and sometimes even in the individual stated of one country. Nevertheless, like in the present case of NSW and Germany, there is a change of laws towards greater sustainability. Like this, the expected damage to the environment must be taken into account already in the planning phase of a mine and the planned rehabilitation measures are defined prior to the mining process.

When it comes to the measures themselves, the undertaken illustrations of the different aspects of rehabilitation showed how complex the implementation of a sustainable restoration is. Fortunately, the necessary activities must be planned even before the mining activities are approved.

To do justice to the intricacy of the mission, specialists from many different subjects have to come 
to a round table to develop a sustainable new ecosystem. Not only knowledge of ecology and biology, chemical processes in the soil, biochemical interactions and technical engineering feasibilities are required but also efficient financial planning is crucial to ensure the practicability later one.

Even if the interventions of the mining industry are violent to the nature, there are promising prospects. If the necessary measures are taken responsibly there are a bunch of possibilities for post mining land usage.

Rehabilitation does not mean that it is necessarily beneficial to reestablish the pre-mined condition, but that it is more sensible to estimate which measures are most likely to succeed. One practice to forecast possible rehabilitation outcomes is to take a look at reference sites, where a similar ecosystem provides information about the most influential parameters.

On top of that, the soil development is one of the most crucial aspects of rehabilitation. This implies a sensitive dumping method and ensuring a microfauna climate in the soil. No matter if the consecutive ecosystem will comprise an aquatic or a terrestrial habitat, problems of $\mathrm{pH}$-values can be remedied by lime treatments.

In order to preserve the genetic potential of a region, seeds and seedlings can be collected prior to clearing the floors. These can then be applied later on to the rehabilitation areas.

Not only the community can profit from a successful rehabilitation when cultivation land is developed or recreation areas are setup, but also threatened species can obtain a new habitat on rehabilitated sites that provides an improved and protected territory for them.

To improve future rehabilitation, a long term monitoring of the existing rehabilitated sites is necessary to understand all progress over time, as well as the continuance of research and development.

\section{References}

[1] NSW Mining. 2013. NSW Mining [Online]. Accessed September

01 ,

2014. http://www.nsemining.com.au/industry/nsw-mining-histo ry.

[2] Office, Parliamentary Councel's. 2012. NSW Legislation [Online]. Accssed September 01, 2014. http://www. legislation.nsw.gov.au/inforcepdf/1992-29.pdf?id=acbe6f e4-8093-c0f3-f8a3-8224663ceb2b.

[3] ABARE. 2001. data.daff.gov.au [Online]. Accessed September $\quad 02, \quad 2014$. http://data.daff.gov.au/data/warehouse/pe_abarebrs 99000 746/PC12214.pdf.

[4] NSW Department of Trade and Investment. 2013. resourceandenergy.nsw.gov.au [Online]. Accessed September 02, 2014. http://www.resourcesandenergy. nsw.gov.au/_data/assets/pdf_file/0016/427021/EDG03Mining,-Rehabilitation-and-Environmental-ManagementProcess-Guide-UPDATED-April-2012.pdf.

[5] ABC. 2015. abc.net [Online]. Accessed October 15, 2015. http://www.generation-bedburg.de/styled-2/files/kaster.jp g.

[6] RWE Power. 2014. rwe.com [Online]. Accessed September $\quad 04, \quad 2014$. http://www.rwe.com/web/cms/de/183406/rwe/innovation/ projekte-technologien/rohstoffe/braunkohle/renaturierung -und-umweltschutz/.

[7] DEBRIV Bundesverband Braunkohle. 2014. DEBRIV Bundesverband Braunkohle [Online]. Accessed September $\quad 02, \quad 2014$. http://www.braunkohle.de/DE/unsere-braunkohle/chronik en/rheinisches-braunkohlenrevier-1978-2014/rheinischesbraunkohlenrevier-1978-2014.html.

[8] Lausitzer und Mitteldeutsche Bergbau-Verwaltungsgesellschaft $\quad \mathrm{mbH} .2009$. Rekultivierung von BergbaufolgelandschaftenNachhaltige Bergbausanierung. Senftenberg, Germany: LMBV Unternehmenskommunikation.

[9] Bundesministerium für Justiz und Verbraucherschutz. 2013. gesetze-im-internet.de [Online]. Accessed September 02, 2014. http://www.gesetze-im-internet. de/bundesrecht/bbergg/gesamt.pdf.

[10] RWE Power. 2013. rwe_rekultivierung_im_rheinland [Online]. Accessed September 02, 2014. http://www.google.de/url?sa=t\&rct=j\&q=\&esrc=s\&frm= $1 \&$ source=web\&cd=2\&sqi=2\&ved $=0$ CCkQFjAB\&url $=$ ht tp\%3A\%2F\%2Fwww.braunkohle.de\%2Findex.php\%3Far ticle_id\%3D98\%26fileName\%3Drwe_rekultivierung_im _rheinland-2013.pdf\&ei=gjoFVO_0FMmMuAT5kYLYD w\&usg=AFQjCNEOUzp-tX5AXF.

[11] Vereinigung Rohstoffe und Bergbau e.V. 2013. Jahresbericht 2013. Berlin: Agreement Werbeagentur $\mathrm{GmbH}$.

[12] Vereinigung Rohstoffe und Bergbau e.V. 2013. Positionen und Perspektiven 2013. Berlin: Vereinigung 
Rohstoffe und Bergbau e.V.

[13] Sander, F. 2013. Sanierung von Bergbaufolgelandschaften der Braunkohle in Sachsen: Rechtliche, technologische, konzeptionelle und finanzielle Parameter [Online]. Accessed September 04, 2014. http://www.google.de/url?sa $=\mathrm{t} \& \mathrm{rct}=\mathrm{j} \& \mathrm{q}=\&$ esrc $=\mathrm{s} \&$ sourc $\mathrm{e}=$ web\&cd $=3 \&$ ved $=0 \mathrm{CCkQFjAC} \&$ url $=$ http $\% 3 \mathrm{~A} \% 2 \mathrm{~F} \% 2$ Fwww.umwelt.sachsen.de\%2Fumwelt\%2Fdownload\%2F Praesentation_Bergbaufolgen_Most_23092013.pdf\&ei=A jIIVPqjF82XuATim4GADw\&usg=AFQjCNEoxYU_qzg k0AAhzTSgWC3zwjQVvQ\&bvm=bv.

[14] Die Welt. 2015. welt.de [Online]. Accessed October 06, 2015.

http:/www.welt.de/regionales/nrw/article142886427/Let zte-Umsiedlungen-fuer-Garzweiler-II-beschlossen.html.

[15] Doley, D., Audet, P., and Mulligan, D. 2012. "Examining the Australian Context for Post-mined Land Rehabilitation: Reconciling a Paradigm for the Development of Natural and Novel Ecosystems among Post-disturbance Landscapes." Sciencedirect 12: 85-93.

[16] Bradshaw, A. 1997. "Restoration of Mined Lands-Using Natural Processes." Ecological Engeneering 8: 255-65.

[17] The great Eastern Ranges. 2014. The Great Eastern Ranges [Online]. Accessed September 03, 2014. http://www.gersteppingstones.org.au/.

[18] Menegaki, M., and Kaliampakos, D. 2012. "Evaluating Mining Landscapes: A Step Forward." Ecological Engineering, 26-33.

[19] Cristescu, R. H., Frère, C., and Banks, P. B. 2012. “A Review of Fauna in Mine Rehabilitation in Australia: Current State and Future Directions." Biological Conservation, 60-72.

[20] Coalface Magazine. 2014. "Rehabilitation Provides Job Joy for Peter." Coalface 8: 14.

[21] The IUCN Red List of Threatened. 2014. The IUCN Red List of Threatened [Online]. Accessed September 05, 2014. http://www.iucnredlist.org/details/6300/0.

[22] Australian Bureau of Agricultural and Resource Economics. 2001. Mine Site Rehabilitation-An Economic Review of Current Policy Issues. Canberra: Commonwealth of Australia.

[23] Glencore. 2013. Annual Environment Review. Mudgee, NSW: s.n.

[24] WHITEHAVEN COAL MINING PTY LTD. 2005. Flora and Fauna Management Plan. Hornsby Nsw; Killara Nsw: Countrywide Ecological Services; Geoff
Cunningham Natural Resource Consultants Pty Ltd.

[25] Peabody Energy, Wilpinjong Coal Pty Ltd. 2013. Licence Monitoring Data Monthly Summary Report [Online]. Accessed September 2014. http://www.peabodyenergy.com/content/427/Australia-M ining/New-South-Wales/Wilpinjong-Mine/Approvals-Pla ns-and-Reports-Wilpinjong-Mine.

[26] ReGen. 2014. Mineregen.com.au [Online]. Accessed September $\quad 04, \quad 2014$. http://www.google.de/url?sa=t\&rct=j\&q=\&esrc=s\&sourc $\mathrm{e}=$ web\&cd $=4 \&$ ved $=0 \mathrm{CDoQFj} A D \&$ url $=\mathrm{http} \% 3 \mathrm{~A} \% 2 \mathrm{~F} \% 2$ Fwww.downergroup.com\%2FDocuments\%2FDowner-M ining-documents\%2FReGen_East_Capabilty-Statement.p df\&ei=A7wHVP-kLY-dugT4-4DADA\&usg=AFQjCNF GYpXXkggkyugdZRP4jLWGZ9i5rA\&bv.

[27] Topp, W. et al. 2001. "Soil Fauna of a Reclaimed Lignite Open-Cast Mine of the Rhineland: Improvement of Soil Quality by Surface Pattern.” Ecological Engineering, 307-22.

[28] RWE Power. 2013. rwe_rekultivierung_im_rheinland [Online]. Accessed September 02, 2014. http://www.google.de/url?sa=t\&rct=j\&q=\&esrc=s\&frm= $1 \&$ source $=$ web \&cd $=2 \&$ sqi $=2 \&$ ved $=0$ CCkQFjAB\&url $=$ ht tp\%3A\%2F\%2Fwww.braunkohle.de\%2Findex.php\%3Far ticle_id\%3D98\%26fileName\%3Drwe_rekultivierung_im _rheinland-2013.pdf\&ei=gjoFVO_0FMmMuAT5kYLYD w\&usg=AFQjCNEOUzp-tX5AXF.

[29] Hüttl, R. F. 2001. "Rekultivierung im Braunkohletagebau-Fallbeispiel Niederlausitzer Bergbaufolgelandschaft." Akademie-Journal 1.

[30] Hüttl, R. F., and Weber, E. 2001. "Forest Ecosystem Development in Post-mining Landscapes: A Case Study of the Lusatian Lignite District." Naturwissenschaften.

[31] Lausitzer und Mitteldeutsche Bergbau-Verwaltungsgesellschaft $\quad \mathrm{mbH} .2009$. Rekultivierung von BergbaufolgelandschaftenNachhaltige Bergbausanierung. Senftenberg, Germany: LMBV Unternehmenskommunikation .

[32] Wismut Gmbg. 2013. 10 Jahre Sanierung von sächsischen Wismut-Altstandorten. Chemnitz: Wismut $\mathrm{GmbH}$.

[33] Vereinigung Rohstoffe und Bergbau e.V. 2013. Jahresbericht 2013. Berlin: Agreement Werbeagentur Gmbh.

[34] Schimmel, C. 2012. "Größter Solarpark: Strom aus Ronneburg für 5600 Haushalte." Ostthüringer Zeitung 5: 10. 